\title{
Overview of Research on Teacher Self-efficacy in Social Cognitive Perspective
}

\author{
Ana Patrícia de Oliveira Fernandez ${ }^{1 *}$, Maély Ferreira Holanda Ramos ${ }^{1}$, Simone Souza Costa e Silva ${ }^{2}$, \\ Karla Cristina Furtado Nina ${ }^{3}$ y Fernando Augusto Ramos Pontes ${ }^{2}$

\begin{abstract}
${ }^{1}$ PhD Student of the Graduate Program in Behavior Theory and Research - Universidade Federal do Pará - UFPA (Brasil).
2 Professor Doctor of the Graduate Program in Behavior Theory and Research - Universidade Federal do Pará - UFPA (Brasil).

${ }^{3}$ Master Degree Student of the Graduate Program in Behavior Theory and Research - Universidade Federal do Pará - UFPA (Brasil).
\end{abstract}

\begin{abstract}
Título: Panorama de las pesquisas sobre autoeficacia docente en la perspectiva social cognitiva.

Resumen: El objetivo de este trabajo fue presentar un panorama de las pesquisas existentes sobre autoeficacia docente. Para tanto, se buscaron artículos en la base de datos de la CAPES y SCIELO periódicos llevado a cabo desde 2009 hasta 2013. Esto resultó en 26 artículos que contemplaban los criterios de inclusión antes establecidos. Los resultados indican que en el análisis de frecuencia de palabras se destacaron los siguientes termos: au toeficacia docente, satisfacción laboral y rendimiento de alumnos. La autoeficacia es influenciada por factores como agotamiento emocional, despersonalización, satisfacción laboral, relación con los padres, uso de la violencia, presión de tiempo, rendimiento académico, manejo de clase, eficacia colectiva entre otros. Tales resultados contribuyen enseñando el sentido de las pesquisas hechas en el área, indicando algunas tendencias y evidenciando lagunas por investigar, por ejemplo, más estudios que verifiquen la relación entre autoeficacia y rendimiento académico, y además, autoeficacia docente y políticas públicas que favorezcan el proceso de enseñanza-aprendizaje.

Palabras clave: Autoeficacia de profesores, teoría social cognitiva, proceso de enseñanza-aprendizaje; panorama de las pesquisas.
\end{abstract}

\section{Introduction}

The concept of self-efficacy is considered as an essential construct within the Social Cognitive Theory of Albert Bandura (1986). This theory explains human behavior taking into consideration the phenomenon of reciprocal causation, this is, individual and environment influencing each other. In this way, social aspects, personal and environmental factors work as determinants of human actions, giving people opportunities to exercise some control over their destinies as well as establishing limits for their self-direction through processes of adaptation and change (Bandura, 1986).

The Social Cognitive Theory developed one of the few concepts related to human control which establishes distinction between competence and contingency, serving as a guide for future actions. From self-efficacy, individuals establish their own way to guide themselves, to regulate and to reflect (Bandura, 2006). Thus, it is understood that people can regulate their own behavior through motivation, affective conditions, actions and challenges from the context based on their efficacy beliefs. The sense of self-efficacy favors a guide which permits people to exercise some influence on how they will conduct their own lives, besides being considered as a key element in the generator system of human competence (Bandura, 1997).

* Dirección para correspondencia [Correspondence address]: Ana Patrícia de Oliveira Fernandez. Alm. Barroso Avenue, 3629, 82 B2 Souza - Postal Code: 66613020 - Belém- PA (Brasil). E-mail: apsol2@hotmail.com; apsol0204@gmail.com
Abstract: The objective of this study was to present an overview of existing researches on self-efficacy teaching. Therefore, researches on articles in the CAPES-Journals and in the SCIELO database were carried out from 2009 to 2013. The survey resulted in 26 articles which consider the inclusion criteria previously established. The results indicate that in relation to the analysis of the frequency words, the following expressions are highlighted: teaching self-efficacy, job satisfaction and students' performance. Self-efficacy is influenced by factors such as emotional exhaustion, depersonalization, job satisfaction, relationship with parents, use of violence, time pressure, academic performance, class management, collective efficacy, among others. These results contribute to signal the direction of the researches which are conducted in the area, indicating some trends and highlighting gaps to be investigated such as a great number of studies that verify the relation between self-efficacy and academic performance as well as self-efficacy teaching and public policy that favor the teaching and learning process.

Key words: Teacher self-efficacy, social cognitive theory, teachinglearning; overview of research.

Self-efficacy beliefs exert influence on the actions that are carried out which may signal improvement or prevention of the action as well as determining how environmental opportunities and difficulties are perceived (Bandura, 2006). Thus, these beliefs affect the choice of tasks, the amount of effort spent in a given action, and how individuals can persevere when they face obstacles (Pajares, 1997).

People with high level of self-efficacy tend to select tasks with higher rates of challenge and difficulty (Bandura, 1997). Similarly, people with low self-efficacy have pessimistic thoughts and, therefore, tend to choose jobs with lesser extent of difficulties. Self-efficacy beliefs determine how people feel motivated and persevere when they face obstacles and choices they make, being considered as an important indicator on how individuals self-regulate actions and thoughts (Bandura, 1997).

The self-efficacy construct has been extensively explored in various fields such as education, administration, health and sport. Particularly in the academic context, studies have shown that self-efficacy beliefs play important roles in the teaching and learning process (Bandura, 1997; Skaalvick \& Skaalvick, 2007; Tschannem-Moran \& Hoy, 2001).

\section{Teacher Self-efficacy}

Teacher self-efficacy has been recognized as an important variable in the last 25 years (Cakiroglu, 2008), considering that it is a concept with very important implications for the educational context, for it represents the teacher's belief in his/her own ability to organize and execute necessary actions required to successfully carry out a specific edu- 
cational task in a particular context (Tschannen-Moran, Hoy, \& Hoy, 1998). To better understand this construct, it is important to highlight that there are two dimensions in this concept: the effectiveness of teaching and personal effectiveness. The first concerns with the ability and competence to achieve positive academic results with the students. The second dimension refers to the belief in the ability to teach effectively (Ashton \& Webb, 1986). It is noteworthy that the working environment has an important influence on the formation and judgment of beliefs, once the teacher, from cognitive processes, analyzes the task to be accomplished by evaluating his/her own competence. In other words, the analysis of the task depends on the educational context as well as from a specific given topic (Tschannem-Moran \& Hoy, 2001).

Bandura (2001) postulates the existence of four generators sources of teacher self-efficacy beliefs: direct experience, vicarious experience, verbal persuasion, affective and emotional states (Bandura, 1997; Jamil, Downer, \& Pianta, 2012). Direct experience is the perception of the past by means of teaching practices; verbal persuasion refers to selfefficacy judgments based on verbal stimulation of other important people such as colleagues, supervisors and managers; vicarious experiences are represented by models of success or failure observed in the actions of other teachers; affective and emotional states are experienced in teaching context and represent the control of the activation level (fatigue, stress, anxiety, tension, mood) that can directly affect the judgment in the ability to teach.

Considering how the teacher self-efficacy beliefs are built, it is understood that there are numerous factors that influence such beliefs and determine how teachers feel, think, self-motivate and behave in their teaching context which are related to several variables. The teacher selfefficacy beliefs are associated with the teachers' behavior in the classroom, the effort that is invested in education, the goals that are set and the level of aspiration and desires (Gibson \& Dembo, 1984; Tschannen-Moran \& Hoy, 2001). Thus, teachers who present strong beliefs of self-efficacy, besides persisting more in difficult situations, risk more in considering new teaching approaches, are more prone to job satisfaction, show more commitment and have low rates of absences at work. This pattern tends to improve the students' academic performance, keeping them more motivated (Gibbs, 2003). Literature also shows that teachers with high self-efficacy beliefs, plan and organize their classes more effectively, are more likely to seek teaching strategies that involve students as well as show great strength to face challenges (Ashton \& Webb, 1986; Midgley, Feldlaufer, \& Eccles, 1989; Tschannen-Moran, 1998).

Studies on self-efficacy beliefs in the educational field have investigated different educational levels and contexts ranging from basic education to higher education, from rural to urban schools (Iaochite \& Azzi, 2012). Several studies have related teacher self-efficacy to variables from the educational context such as students' outcomes (Caprara, Bar- baranelli, Steca, \& Malone, 2006), motivation (Boruchovitch \& Bzuneck, 1996) and student self-efficacy (Caprara, Vecchione, Alessandri, Gerbino, \& Barbaranelli, 2011). In addition, teachers' efficacy beliefs are also related to their behavior in the classroom with regard to the effort dedicated to teaching, the goals they set as well as their level of aspiration (Tschannen-Moran \& Hoy, 2002).

The international literature related to teachers' effectiveness has been signaling growth in the area in recent decades, as shown in the systematic review of Klassen, Tze, Betts and Gordon (2011). They presented a critical overview and description of existing researches in the area from 1998 to 2009. Among the results, the study shows gaps to be investigated such as the relationship between teacher's effectiveness and students' school performance, the use of diversified methodologies besides those from quantitative researches, researches on sources of teacher's effectiveness, great attention to specific areas, internationalization of researches, expanding the scope of these researches to further studies which are conducted in North America, more researches on teacher's collective efficacy.

The publication of studies in a systematic review as the study of Klassen et al. (2011) is considered fundamental to scientific development, since it favors comparisons of findings in longitudinal terms, points out results and signals gaps found in the literature which help researchers to better target their efforts. Thus, understanding that the mapping of studies on a given topic may constitute a relevant contribution to researchers, this systematic review aims to present an overview of the researches on teacher self-efficacy, conducted from 2009 to 2013, through the identification of rules of association among the keywords as well as the presentation of networks of relations among variables found in the results of the investigated articles.

\section{Method}

This study is characterized as systematic review of the literature on teacher self-efficacy. Criteria for search procedures and selection of material for analysis have been established. It was inspired by the principles of Evidence-Based Medicine $(\mathrm{EBM})$, based on the guidelines of the Cochrane Collaboration for conducting systematic reviews. Despite being directed to clinical studies, intervention and accuracy, it is understood that such provisions can be adapted to fit the specificities of systematic reviews from other nature, which is the case of this research. So this review was carried out in seven steps: (a) formulation of the question, (b) location and selection of the studies, (c) critical evaluation of the articles, (d) data collection, (e) analysis and presentation of data (f) interpretation of data, (g) review improvement (Rother, 2007; Sousa \& Ribeiro, 2009).

The first step was to define the question that guided this review. To define the question, the PVO technique was used, where $\mathrm{P}$ refers to the problem situation, participants or context; $\mathrm{V}$ refers to the study variables; $\mathrm{O}$ refers to the out- 
come or expected result. The PVO technique is an adaptation of the PICO model that fulfills researches which deal with issues related to psychology or related fields. The PICO model intended for clinical studies of intervention where $\mathrm{P}$ refers to the participants, I refers to intervention, $\mathrm{C}$ refers to control and results (Biruel \& Pinto, 2011). Such techniques help to organize the elements of a research to structure the questions. Thus, from the PVO technique, it was possible to ask the following questions: What is the panorama of researches on teacher self-efficacy, based on the Cognitive Social Theory, published from 2009 to 2013? The following formula is considered: $\mathrm{P}$ (problem situation, participants or context) - teachers in schools; $\mathrm{V}$ (study variable) - selfefficacy; O (expected result) - identify the panorama of studies on the topic in question.

The second step involved the definition of search terms. For this, we used the PVO scale, identifying, within the realm of possibility, descriptors for each component of the PVO strategy, representing free words related to the subject investigated. Thus, as search terms the following keywords were used: teacher self efficacy beliefs, teacher self efficacy, self efficacy, teacher beliefs, academic performance, academic achievement, school, school context, educate, learning as well as their equivalents in Portuguese. After defining the descriptors, they were submitted to DeCS - Descriptors of Health Science.

The construction of the search strategy to be submitted to database was done. To be effective, the search strategy needs to be well prepared, involving a controlled vocabulary and connected to properly Boolean operators (Sampaio, 2013). Thus, the Boolean operators were applied to each component of the PVO scale, comprising the following structure: $(\mathrm{Q})$ and $(\mathrm{V})$ and $(\mathrm{O})$. So, the search strategy in the form of equation was formed ("teacher self efficacy beliefs" OR "teacher self efficacy" OR "self efficacy" OR "teacher beliefs") AND ("school" OR "school context") AND ("academic performance" OR "academic achievement" OR "educate" OR "learning").

All articles were selected from the search engines of two academic directories: CAPES/ Periodicals and Scielo. CAPES is one of the largest virtual libraries in the world, containing scientific content of high level, with national and international publications, from the most varied areas of knowledge, among them psychology and education. Scielo is an electronic library covering a selected collection of periodicals with prominence in Latin-America. The following inclusion criteria were adopted: include "in the title," "exact", the term teacher self efficacy, to be complete and available, articles published in English and Portuguese, from 2009 to 2013 in periodicals peer-reviewed, focusing on the investigation of teacher self-efficacy based on the Social Cognitive Theory. In this initial search, 98 articles were found in the virtual library of CAPES/Journal. Throughout the process, $61 \mathrm{ob-}$ jects were discarded because they were repeated or were not available for download, totaling 37 articles of which 11 were excluded because they did not fit into the inclusion criteria mentioned above, with only a total of 26 articles left for this analysis. In Scielo, from the descriptors, 17 articles were found of which only two met the inclusion criteria; however, such articles had already been selected in the researches made in the CAPES database/Journals, not representing an increase in the amount of articles included in this review. The other articles were either in Spanish or repeated, or were not applied to teacher self-efficacy.

A critical evaluation of the studies was carried out through the application of two important tests, being conducted by a judge: Initially, Relevance Test I was applied to 37 abstracts and methods of articles available for download with six objective questions, besides the inclusion and exclusion criteria. The questions offered the possibilities of positive and negative answers, as in the following examples: Is the study in accordance with the investigated theme? Was it published in the stipulated time? Is it a study of teachers? Was it published in the languages specified in the research proposal? Does it have free access to researchers? Does it make use of the construct teacher's self-efficacy from the Social Cognitive Theory? The remaining findings of this refinement process totaled 26 articles that were submitted to the Relevance Test II which had 100\% of agreement between the two raters. For the Relevance Test II, only the approved articles in the Relevance Test I were included. Test II was applied by two researchers in the field, consisting of the following questions: Is the objective of the study related to what is being studied? Is the method clearly described? Do the results deserve credibility? (Azevedo, 2010). After that, the collection of data in the articles was done in order to define the variables found in the studies. This step and the following sequence were considered. The first step was the statistic calculation of the general tendency that informed the sample in its totality or average (Cozby, 2003).

Aiming to present the network of relations among the keywords and the variables found in the results and perform cluster analysis, the software NodeXL was used. Such tool builds structures of network of relations using graphics in which the nodes represent the vertices and the edges show the relations among network elements (Matei, 2011).

Knowing that there are several ways to measure the importance of a vertex in a network, the option for certain metrics were selected, such as: (2) Degree of Centralization (Degree / in-degree / out-degree) (Betweenness Centrality) - was used to evaluate how much a vertex is in the geodesic path between two other vertices, that is, to analyze the importance of a vertex when passing information between the other two; Node Relevance (PageRank) - was used to measure the level of importance of a node in the network in guided graphics; to identify the most important terms, the analysis of the frequency of the words was carried out.

\section{Results}

\section{Keyword - Frequency words}

A bibliometric analysis stands out in the academic surroundings as an important metric science of content analy- 
sis, able to analyze the direction of the written communication as well as to infer about the bibliographic production of a particular field of knowledge. This technique was used aiming to identify the frequency of the investigated terms. Shortly after the investigation, a total of 63 words were found. Textual data visualization technique from free software of content analysis called Many Eyes was used. The chosen technique (Word Cloud Generator) allows the visualization of the frequency and the degree of prominence of the keywords. Figure 1 shows the levels of importance of these words in the data set of the investigated articles. Such presentation helps to inform that larger is the size of the word, greater are the absolute and relative frequencies of it, showing the importance and presence of the words in the studies related to the theme on the sample of teacher selfefficacy of this research. The first three keywords of each article were used, having been compacted those with the same meaning.

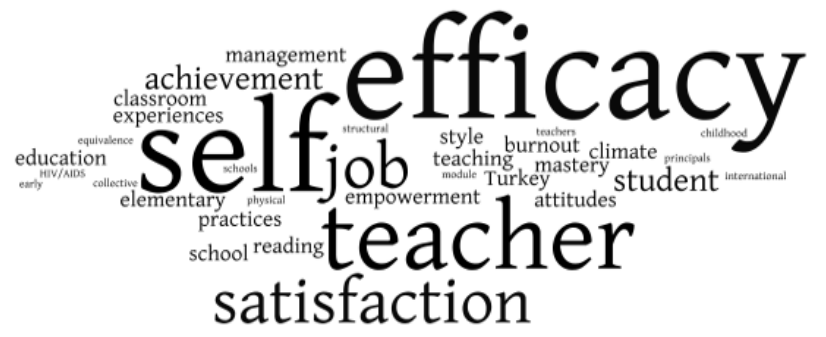

Figure 1. Frequency and degree of prominence of the keywords.
Figure 1 shows a graphical visualization of the most frequent keywords. The words which featured more were, for example self, efficacy, teacher, satisfaction, achievement, classroom, management, achievement, job, burnout, students, school, elementary, education, styles, attitudes, among others, allow to perceive some directions of the conceptual production concerning the investigation of the teacher self-efficacy construct, indicating the tendency of researchers to investigate certain issues over others. The level of importance of each word is related to the size and frequency of appearance in the articles.

Analyzing the frequency of the words, the following terms were highlighted: teaching self-efficacy, job satisfaction and performance of students. It is worth mentioning that despite the analysis help differentiate which keywords are being used more often in literature; it shows little in terms of the scope of relations among themes investigated, that is, the field of relations among such keywords that literature has investigated. It is in this sense that the description of the network of relations among keywords can show more clearly which relations among variables and themes literature has investigated.

\section{Network relations among keywords}

The representation of keywords and their relations in the form of networks can be considered by means of obtaining information more efficiently in certain contexts, contributing to its correct interpretation. To investigate the association rules among the articles in this study from its keywords, the NodeXL tool was used to analyze probable networks of relations. Figure 2 shows the relations among the found terms.

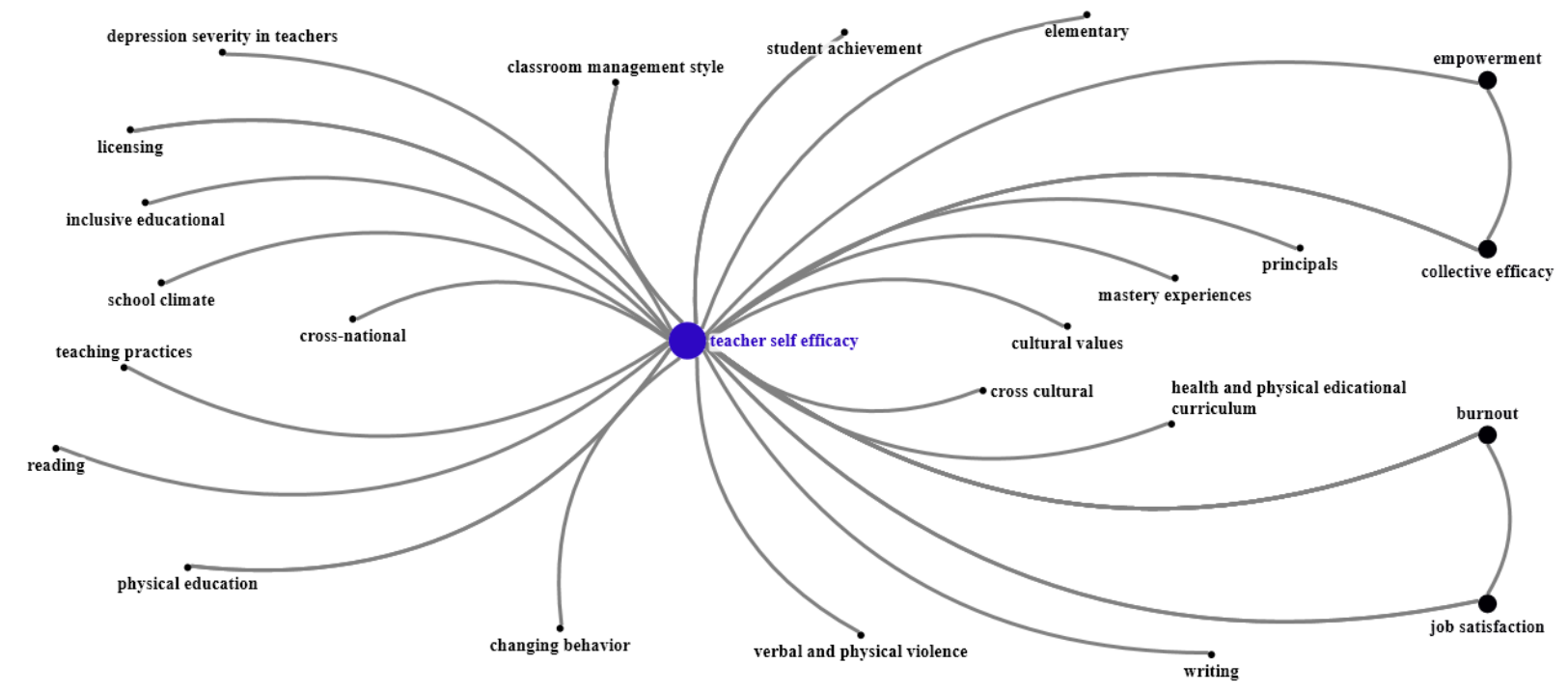

Figure 2. Multigraphic - Network of relations among keywords.

Figure 2 consists of a multigraphic which indicates the connection among the keywords, from the joint frequency of the terms, without; however, disclosing the direction among these relations. A multigraphic is a graphical which brings together multiple or parallel edges between pairs of vertices.

For the purposes of highlighting the importance of a keyword in the network of knowledge researched, the metric 
Eigenvector centrality was calculated and defines the relevance of a node (keyword) in the entire network of words based on the importance of nearby nodes. Thus, a keyword is more important in the network according to the nearby nodes that have more relations in the network. For this reason, it was possible to observe that the term teacher self-efficacy achieved the highest result (0.16) which confirms the interest in this vertex, ensuring its level of importance. The other featured elements were taking as the cut off point words with metric above 0.043 , respectively: burnout $(0.04)$, collective efficacy (0.04), job satisfaction (0.04), empowerment (0.04). In Figure 2.2 , it is possible to observe the main vertices according to the size of the circles, in other words, larger is the size of the circles, larger is the result of the centrality measure.

It was possible to notice that the teacher self-efficacy term appeared related to the following terms: academic performance of students, class management, elementary school, principals, vicarious experiences, cultural values, physical education curriculum, reading, school environment, teaching practice, work satisfaction, collective efficiency, among others.

With the first technique (frequency analysis) used through the software Many Eyes, the analysis of free and simple keywords was done. The second technique (analysis of network of relations) explored these terms in its original form, sometimes with simple words, sometimes with compound words. This may explain the differentiated frequency of appearance of such descriptors. In the analysis of the network of relations with graphics, the following keywords were considered the most important ones: self-efficacy, collective efficacy and burnout, job satisfaction and empower- ment, considering the order of importance of each vertex in the multigraphic. This indicates a tendency for researchers to investigate the relation between self-efficacy with such terms.

Concerning the analysis of networks of relations, the metric that defines the importance of a node in the whole network of words was calculated (Eigenvector centrality) to identify which vertex (element) is referenced more by the others. It could be observed that the term teacher self efficacy achieved the highest result $(0,16)$ which confirms the interest in this vertex, ensuring its level of importance. The other featured elements were taking as the cut off point the words with metric above 0,043 , respectively: burnout $(0,04)$, collective efficacy $(0,04)$, job satisfaction $(0,04)$, empowerment $(0,04)$.

\section{Analysis of the results of the articles}

Relations among the variables identified in the studies on teacher self-efficacy

For the analysis of the results, a study of the relations among the variables listed in the articles was done. The NodeXL tool was used to explore variables. The multigraphics shown in the figures below indicate the relations among the variables identified in the studies on teacher self-efficacy, from the results of researches undertaken in the field from 2009 to 2013. The multigraphics were generated in two groups: (a) positive correlations and (b) negative correlations. Figure 3 illustrates the networks of positive correlations.

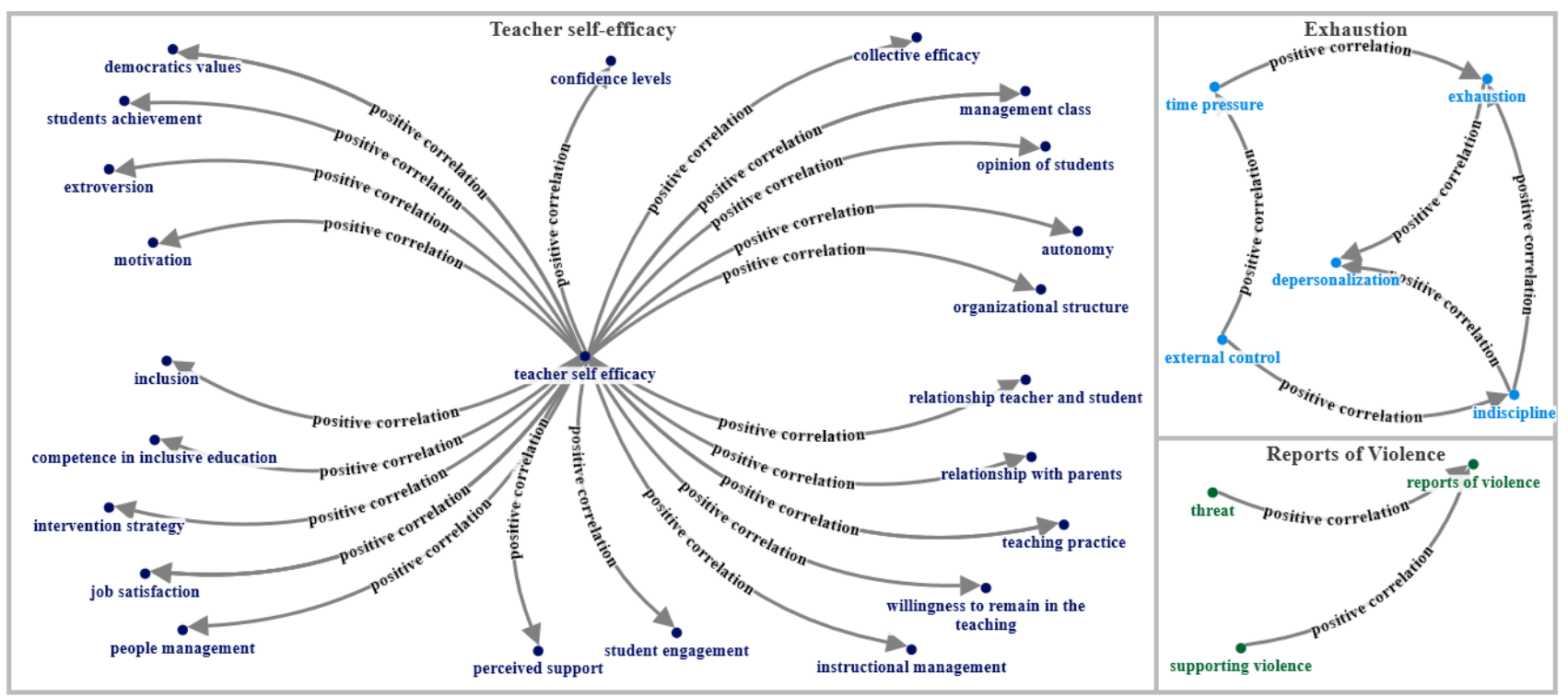

Created with NodeXL (http://nodexl.codeplex.com)

Figure 3. Multigraphic - Network of positive correlations among variables.

As it is possible to observe, Figure 3 is related as directed multigraphic (which indicates the direction of the relation through arrows) of relation among the variables found in the investigated articles. The most important vertices in this 
multigraphic were highlighted, that is, the ones which show greater potentiality to mediate the connections, by means of circles, on scale of blue tones and brought into prominence. For the selection of the most important elements, the vertices with PageRank $>0.8$ were considered. This criterion was established because vertices with scores $>0.8$ were found to have a greater frequency in the selected articles. Thus, the vertices that connected more and mediated links were (in order of importance): (1) self-efficacy and (2) emotional exhaustion. From the visualization of Figure 3 above, it was found that teaching self-efficacy was the vertex that stood out more, connecting itself with other 22 vertices and reaching the highest score of relevance (PageRank 10.6). It is worth mentioning that the variables that did not appear in the graphic and obtained vertices with PageRank < than 0.8 were the following: teaching English and math (Garvis, 2012; Garvis \& Pendergast, 2011), Italian version of the Norwegian scale positive behavioral approach (Avanzi et al., 2013). The only variable that did not show correlation with teacher self-efficacy was teaching conceptual changes (Lee, Cawthon, \& Dawson, 2013).

The first and most important vertex highlighted in Figure 3 is teacher self-efficacy which appears positively correlated with class management (Silva, Iaochitte, \& Azzi, 2010; Abu-Tineh, Khasawneh, \& Khalaileh, 2011), motivation (Shaukat \& Iqbal, 2012, Kopcha \& Alger, 2011; Mojavezi \& Tamiz, 2012), job satisfaction (Kelm, 2012), democratic values (Topkaya \& Yavuz, 2011), autonomy (Skaalvik \& Skaalvik, 2010), relationship of the parents, collective efficacy (Kurt, Duyar, \& Calik, 2012), relationship between teacher and student (Kim \& Kim, 2010), school performance (Corkett, Hatt, \& Benevides, 2011; Mojavezi \& Tamiz, 2012), desire to remain in the profession (Iaochitte, Azzi, Plydoro, \& Winterstein, 2011), inclusion (Tschannen-Moran \& Johnson, 2011; Malinen et al, 2013); teaching practice (Pan, Chou Hsu, Li, \& Hu, 2013; Vieluf, Kunter, \& Vijver, 2013); school's organizational structure (Hemric, Eury, \& Shellman, 2010).

The second vertex highlighted was emotional exhaustion connecting itself to three different variables (Skaalvik \& Skaalvik, 2010) and reaching the second highest score of relevance (PageRank 0.88). It presented positive correlation with depersonalization. This multigraphic also shows that vertices indiscipline and time pressure were related to exhaustion and that external control is connected with the variable pressure of time and this, in turn, connected itself to emotional exhaustion.

Emotional exhaustion composes one of the three dimensions of the burnout syndrome defined as a situation in which the employee perceives his emotional resources depleted in the face of adversities of everyday work (Sousa, 2009). Among the articles raised in this systematic review, $11.4 \%$ of the total of the findings found positive correlations among exhaustion and the variables: time pressure (3.8\%), discipline (3.8\%), depersonalization (3.8). Among these, the research done by Skaalvik and Skaalvik (2010) explored the relations among teacher self-efficacy, collective efficacy, teacher's burnout, job satisfaction and teachers' beliefs that teaching outside factors impose limits on the teacher's work. Among the results, indiscipline had a weak, but significant correlation with both emotional exhaustion (13) and with depersonalization (11) which are the two dimensions of teacher's burnout. These two variables showed weak correlation between each other, but positive (23). Finally, it was observed that disciplinary problems may contribute to trigger depersonalization and emotional exhaustion (Skaalvik \& Skaalvik, 2010).

The variable reports of violence was the last most relevant vertex of the multigraphic (Figure 3) indicating connection with the vertices threat and support of the use of violence. Among the results, the research of Khoury-Kassabri (2012) verified that the greatest support in relation to the use of physical violence or verbal was significantly correlated with great frequency to the reports of the use of violence with students and higher levels of threat related to them. In this sense, Khoury-Kassabri (2012) believe that this association must be taken into consideration in order to foster attitudes towards intervention programs and teacher training.

\section{Negative correlations}

Figure 4 shows the multigraphic of the network of negative relations among variables with three major vertices: (a) teaching self-efficacy; (b) depersonalization; (c) job satisfaction. 


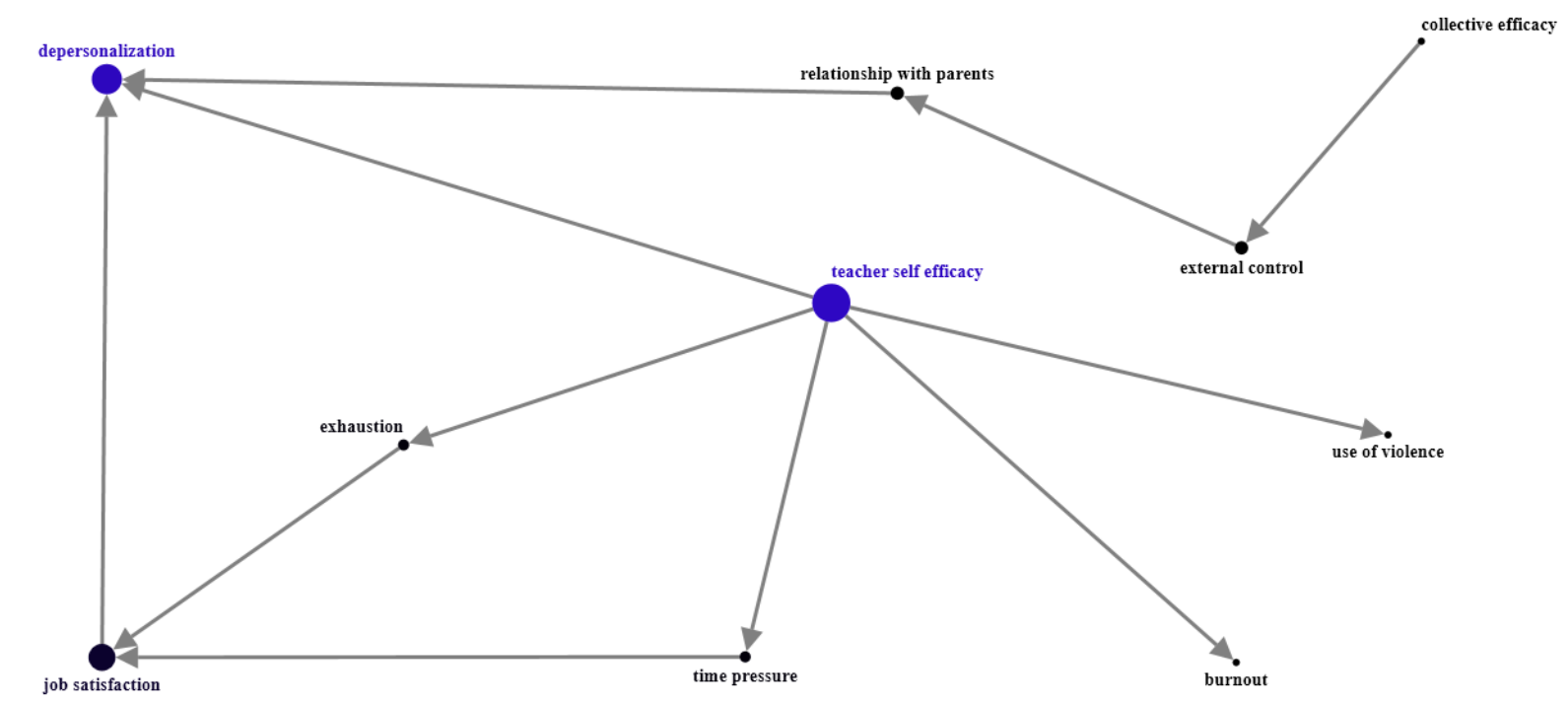

Figure 4. Multigraphic - Network of negative correlations.

From the most important elements, the vertices with PageRank $>1,2$ was considered. The teacher self-efficacy vertex was the most important (PageRank 2,1) connecting itself to the five different elements of the multigraphic (Figure 4), presenting negative correlation with the following variables: depersonalization, exhaustion, time pressure, burnout syndrome and use of violence. Other indirect connections with teaching self-efficacy were also observed, namely: job satisfaction, relationship with the parents and collective effectiveness. It is worth mentioning that the variables which did not appear in the graphic obtained vertices with PageRank < than 0,8. These variables were knowledge of arts (Garvis \& Pendergast, 2011) and music teaching (Garvis, 2012).

In this review, the study of Skaalvik and Skaalvik (2010) verified the teachers' beliefs in relation to external control, that is, in relation to factors that are beyond the educational context, influencing the capability to teach. It was observed that external control showed a negative, but weak correlation with both self-efficacy and collective efficacy. The results also suggest that external control should be analyzed differently both with respect to self-efficacy and to collective efficacy. Teacher self-efficacy showed negative correlation with emotional exhaustion and with time pressure.

Moreover, in the study of Skaalvik and Skaalvik (2010), the term teacher self-efficacy showed a direct negative correlation with the second important vertex that was the depersonalization (PageRank 1,5). This vertex had a direct negative correlation with the variable job satisfaction and relationship with parents. It was found that the variable relationship with parents was negatively associated with depersonalization (.44).

The third relevant vertex of this multigraphic (Figure 2.4) was job satisfaction (Pagerank 1,2). It was observed that both emotional exhaustion as well as time pressure are negatively associated with job satisfaction which was interconnected to depersonalization, whose association (-.52) was found in the work of Skaalvik and Skaalvik (2010), showing that higher is the emotional exhaustion, lower is the teacher's job satisfaction.

\section{Discussion}

The panorama of research raised in this systematic review of teacher self-efficacy, through the studies on the relations among the variables investigated in the articles and through the multigraphics, presented important indications of researches preformed on the investigated construct. In this way, understanding such construct reflects the need to know how the relation among self-efficacy and its variables are involved in the teacher's work context.

The researches found signaled the need to understand how self-efficacy is part of the educational context, being influenced by both intrinsic factors, such as those related to class management (Abu-Tineh, Khasawneh and Khalaileh, 2011) or to the student's academic performance (Bandura, 1997, 1998; Kaçkaya, 2011; Mojavezi \& Tamiz, 2012; Soodak \& Podell, 1996), among others as well as by external teaching factors that sometimes impose limits on the teacher's work (Skaalvik \& Skaalvik, 2010).

Being self-efficacy at the central pillar of the Social Cognitive Theory, it is understood that a number of meaningful positive correlations found in this review may be related to the influence that this variable has on the teacher's work context, reveling mostly the level of interest of the researchers in this area of knowledge. It is not by chance that researches have shown positive effects among self-efficacy and various aspects of the teacher's educational context, such as 
between teaching self-efficacy and academic performance (Anthony \& Kritsonis, 2007; Klassen et al, 2011; Mojavezi \& Tamiz, 2012), teaching self-efficacy and motivation (NolenHoeksema, Stice, Wade, \& Bohon, 2007), teacher selfefficacy and class management (Abu-Tineh et al, 2011); selfefficacy and job satisfaction (Caprara et al., 2006). In this way, Cheung, Richler, Palmeri and Gaultier (2008) postulate that high levels of self-efficacy are positively associated with both the students' academic results and with higher degree of motivation as well as with the belief in their own ability, which is consistent with the idea that teacher self-efficacy was established as a strong predictor of productive teaching practices (Abu-Tineh et al., 2011).

The variable emotional exhaustion was the second variable with the greatest evidence raised in the studies, without considering the separation of articles into groups of positive and negative correlations. However, of the 26 articles in this review, only one study investigated the relationship among emotional exhaustion with time pressure, indiscipline and depersonalization, suggesting that higher the levels of time pressure, indiscipline and depersonalization, greater the levels of emotional exhaustion which confirmed the findings, such as the ones found in Skaalvik and Skaalvik (2010). Teachers who tend to have low expectations in the classroom are more prone to occupational stress, raising the levels of emotional exhaustion and depersonalization. In this sense, the school must consider all actions in favor of better conditions of work. Teachers' work must be in accordance with the objectives and with the philosophy of the school context (Skaalvik \& Skaalvik, 2007).

To a more limited extent, but evident, is the case of the vertex violence of reports which showed positive associations with the vertices threat and support the use of violence, pointing out that the use of support can also affect the tendency to use emotional violence by the teachers towards their students. Although this review has found only one study verifying the association of the variables in question, literature alerts to the fact that $1 / 3$ of the teachers reveal that they use physical or verbal violence in the classroom (KhouryKassabri, 2012).

It was observed that some vertices (Figure 2.4) showed negative associations between each other. It was noticed that

\section{References}

Abu-Tineh, A. M., Khasawneh, S. A., \& Khalaileh, H. A. (2011). Teacher self efficacy and classroom management styles in jordanian schools. Management in Education, 25 (4), 175-181. doi:10.1177/0892020611420597*

Anthony, T. \& Kritsonis, W. (2007). A mixed methods assessment of the effectiveness of strategic e-mentoring in improving the self-efficacy and persistence (or retention) of alternatively certified novice teachers within an inner city school'. District Doctoral Forum National Journal for Publishing and Monitoring Doctoral Student Research, 4, 1-8.

Ashton, P. T., \& Webb, R. B. (1986). Making a difference: Teachers' sense of efficacy and student achievement. New York: Longman.

Avanzi, L., Miglioretti, M., Velasco, V., Balducci, C., Vecchio, L., Fraccaroli, F., \& Skaalvik, E. M. (2013). Cross-validation of the norwegian higher are the depersonalization rates, exhaustion, time pressure, burnout syndrome and use of violence, lower are the teacher self-efficacy scores. It was also observed that higher the relationship with parents, lower the depersonalization as well as greater the job satisfaction, lower the exhaustion. These data suggest that negative aspects experienced in teaching environment contribute to rethink teacher's labor process in which is evidenced the losses and damages both in the professional's career as well as in the social and family life (Pinto-Silva \& Heloani, 2009).

\section{Final Considerations}

This systematic review has provided information on the research conducted on teacher self-efficacy, making it possible to identify associations among the items from the keywords and categorical variables analyzed in the results of the articles. It was found that researchers have sought to investigate the teaching self-efficacy from their possible relationships with the various variables in the teacher's working environment. In terms of theoretical implications, such result contributes to signal the direction of the researches conducted in the area, pointing out some trends in the investigated topic. It is worth mentioning that the network analysis technique with graphics was both adequate for the analysis of keywords and for the results.

Among the limitations of this study, some gaps were found to be investigated: (a) Among the criteria for inclusion, the choice for only articles excluded the possibility of checking other types of studies, such as theses and dissertations (b) The choice for only articles in English and in Portuguese. (c) The use of only two database (periodicals / Capes and Scielo). Future studies could, for example, expand the searches, performing researches on different types of academic publications such as theses and dissertations, include studies in other languages other than English and Portuguese as well as include other database as a source of research. Nevertheless, it is believed that the sample of articles pre-defined in this study represents the current state of the area investigated.

teacher's self-efficacy scale (NTSES). Teaching and Teacher Education, 31, 69-78. doi:10.1016/j.tate.2013.01.002*

Azevedo, R. S. (2010). Sobrecarga do cuidador informal da pessoa idosa frágil: Uma revisão sistemática. Dissertação de Mestrado.

Bandura, A. (1986). The explanatory and predictive scope of self-efficacy theory. Englewood Cliffs, NJ: Prentice Hall.

Bandura, A. (1997). Self-efficacy: The exercise of control. New York: W. H. Freeman. Retrieved from http://books.google.com/books?id=eJPN9g_o-

EC\&printsec $=$ frontcover\&dq $=$ bandura + isbn: $9780716728504 \&$ hl $=$ en \& ei=HAwYTbKsLpTmsQPp8cCPCg\&sa=X\&oi=book_result\&ct=resul t\&resnum $=1 \&$ ved $=0$ CCMQ 6 AEwAA $\# \mathrm{v}=$ onepage $\& \mathrm{q} \& \mathrm{f}=$ false 
Bandura, A. (1998). Health promotion from the perspective of social cognitive theory. Psychology \& Health, 13 (4), 623-649. doi:10.1080/08870449808407422

Bandura, A. (2001). Social Cognitive Theory: An agentic perspective. Annual Review of Psychology, 52, 1-26.

Bandura, A. (2006). Toward a psychology of human agency. Perspectives on Psychological Science, 1, 164-180.

Biruel, E. \& Pinto, R. (2011). Bibliotecário: Um profissional a serviço da pesquisa. Anais do XXIV Congresso Brasileiro de Biblioteconomia, Documentação e Ciência da Informação. Maceió, Alagoas, Brasil.

Boruchovitch, E. \& Bzuneck, J. A. (1996). As crenças de auto-eficácia e o seu papel na motivação do aluno. Editora Vozes, 1, 1166-133.

Caprara, G. V., Barbaranelli, C., Steca, P., \& Malone, P. S. (2006). Teachers' self-efficacy beliefs as determinants of job satisfaction and students' academic achievement: A study at the school level. Journal of School Psychology, 44 (6), 473-490. doi:10.1016/j.jsp.2006.09.001

Caprara, G. V., Vecchione, M., Alessandri, G., Gerbino, M., \& Barbaranelli, C. (2011). The contribution of personality traits and self-efficacy beliefs to academic achievement: A longitudinal study. The British Journal of Educational Psychology, 81(1), 78-96. doi:10.1348/2044-8279.002004 *

Cakiroglu, E. (2008). The teaching efficacy beliefs of pre-service teachers in the USA and Turkey. Journal of Education for Teaching, 34, 33-44.

Cheung, O. S.; Richler, J. J.; Palmeri, T. J. \& Gauthier, B. (2008). Revisiting the role of spatial frequencies in the holistic processing of Faces. Journal Experimental Psychology, 34, 1327-1336.

Chang, S. (2010). Academic genealogy of mathematicians (1a ed.). World Scientific Publishing Company.

Corkett, J., Hatt, B., \& Benevides, T. (2011). Student and teacher selfefficacy and the connection to reading and writing. Canadian Journal of Educational, $34 \quad$ (1), 65-98 Retrieved from http:/ / search.ebscohost.com/login.aspx?direct $=$ true\&profile=ehost\&s cope $=$ site $\&$ authtype $=$ crawler\&jrnl $=03802361 \& A N=67026450 \& \mathrm{~h}=8 \mathrm{JQ}$ 8kRTmWV7vVVZ4f5Lm2BTtRigqQVLaXyJ4XcSSRJGCxut9TV\%2F P1R1J9A7qNQK\%2FL5FtxlAktTfYFvnwzn7w4w\%3D\%3D\&crl=c *

Cozby, P. C. (2003). Métodos de pesquisa em ciências do comportamento. Retrieved September 29, 2014, from http://minhateca.com.br/PabloStuart/Documentos/An*c3*a1lise+do + Comportamento/Cozby*2c+P.+C.+(2003). $+\mathrm{M}^{*} \mathrm{c} 3 * \mathrm{a} 9$ todos $+\mathrm{de}+$ pes quisa + em $+\mathrm{ci}^{*} \mathrm{c} 3 *$ aancias + do + comportamento, 1983645.pdf

Garvis, S. (2012). Beginning generalist teacher self-efficacy for music compared with maths and English. British Journal of Music Education, 30, 85-101. doi:10.1017/S0265051712000411*

Garvis, S., \& Pendergast, D. (2011). An investigation of early childhood teacher self-efficacy beliefs in the teaching of arts education. International Journal of Education \& the Arts, 12, 45-58*

Gibbs, C. (2003). Explaining effective teaching: Self- efficacy and thought control of action. Journal of Educational Enquiry, 4, 1-14. Retrieved from http://www.literacy.unisa.edu.au/jee/Papers/JEEVol4No2/Paper1.pd f

Gibson, S., \& Dembo, M. H. (1984). Teacher efficacy: A construct validation. Journal of Educational Psychology, 76(4), 569-582. doi:10.1037//0022-0663.76.4.569

Hemric, M., Eury, A. D., \& Shellman, D. (2010). Correlations between perceived teacher empowerment and perceived sense of teacher selfefficacy. Journal of schoolarship and Practice, 7, 37-50*

Iaochite, R., \& Azzi, R. (2012). Escala de fontes de autoeficácia docente: Estudo exploratório com professores de Educação Física. Psicol. Argum, $30(71), 659-669 *$

Iaochite, R. T., Azzi, R. G., Polydoro, S. A. J., \& Wintertein, P. J. (2011). Autoeficácia docente, satisfação e disposição para continuar na docência por professores de educação física. Revista Brasileira de Ciências e Esporte, 33, 825-839*

Jamil, F. M., Downer, J. T., \& Pianta, R. C. (2012). Association of preservice teachers' performance, personality, and beliefs with teacher selfefficacy at program completion. Teacher Education Quarterly, 39, 119-138. Retrieved

from

http:/ /ezproxy.usherbrooke.ca/login?url=http:// search.ebscohost.com $/$ login.aspx?direct $=$ true $\& \mathrm{db}=$ eric $\& \mathrm{AN}=\mathrm{EJ} 1001446 \&$ site $=$ ehost live \nhttp://www.teqjournal.org/*
Kaçkaya, A. (2011). The effect of school and teacher themed movies on preservice teachers' professional attitudes and perceived self-efficacy. Educational Sciences: Theory \& PracticeEducational Sciences: Theory \& Practice, $11,1778-1783 *$

Kelm, J. L. (2012). Effects of school-wide positive behavior support on teacher self-efficacy. Psychology in the Schools, 49, 137-147. doi: $10.1002 /$ pits *

Khoury-Kassabri, M. (2012). The relationship between teacher self-efficacy and violence toward students as mediated by teacher's attitude. Social Work Research, 36, 127-139. doi:10.1093/swr/svs004 *

Kim, Y. H., \& Kim, Y. E. (2010). Korean early childhood educators' multidimensional teacher self-efficacy and ECE center climate and depression severity in teachers as contributing factors. Teaching and Teacher Education, 26, 1117-1123. doi:10.1016/j.tate.2009.06.009*

Klassen, R. M., Tze, V. M. C., Betts, S. M., \& Gordon, K. a. (2011). Teacher efficacy research 1998-2009: Signs of progress or unfulfilled promise? Educational Psychology Review, 23 (1), 21-43. doi:10.1007/s10648-0109141-8*

Kopcha, T. J., \& Alger, C. (2011). The impact of technology-enhanced student teacher supervision on student teacher knowledge, performance, and self-efficacy during the field experience. Journal of Educational Computing Research, 45 (1), 49-73. doi:10.2190/EC.45.1.c*

Kurt, T., Duyar, I., \& Çalik, T. (2012). Are we legitimate yet?: A closer look at the casual relationship mechanisms among principal leadership, teacher self-efficacy and collective efficacy. Journal of Management Development, 31(1), 71-86. doi:10.1108/02621711211191014*

Lee, B., Cawthon, S., \& Dawson, K. (2013). Elementary and secondary teacher self-efficacy for teaching and pedagogical conceptual change in a drama-based professional development program. Teacher an Teacher Educational, 30, 84-98*

Malinen, O.-P., Savolainen, H., Engelbrecht, P., Xu, J., Nel, M., Nel, N., \& Tlale, D. (2013). Exploring teacher self-efficacy for inclusive practices in three diverse countries. Teaching and Teacher Education, 33, 34-44. doi:10.1016/j.tate.2013.02.004*

Matei, S. (2011). Analyzing social media networks with NodeXL: Insights from a connected world by Derek Hansen, Ben Shneiderman, and Marc A. Smith. International Journal of Human-Computer Interaction, 27, 405-408.. doi:10.1080/10447318.2011.544971

Midgley, C., Feldlaufer, H., \& Eccles, J. S. (1989). Change in teacher efficacy and student self- and task-related beliefs in Mathematics during the transition to Junior High School. Journal of Educational Psychology, 81, 247-258.

Mojavezi, A., \& Tamiz, M. P. (2012). The impact of teacher self-efficacy on the students' motivation and achievement. Theory and Practice in Language Studies, 2, 483-491. doi:10.4304/tpls.2.3.483-491*

Nolen-Hoeksema, S., Stice, E., Wade, E., \& Bohon, C. (2007). Reciprocal relations between rumination and bulimic, substance abuse, and depressive symptoms in adolescent females. Journal of Abnormal Psychology, 116 (1), 198-207

Pajares, F. (1997). Current directions in self-efficacy research. In H. W. Marsh, R. G. Craven, \& D. M. McInerney (Eds.), International advances in self research, 32, 1-49. Greenwich, Connecticut: Information Age Publishing.

Pan, Y.-H., Chou, H.-S., Hsu, W.-T., Li, C.-H., \& Hu, Y.-L. (2013). Teacher self-efficacy and teaching practices in the health and physical education curriculum in Taiwan. Social Behavior and Personality: An International Journal, 41, 241-250. doi:10.2224/sbp.2013.41.2.241*

Pinto-Silva \& Heloani, R. (2009). Gestão educacional e trabalho docente: Aspectos socioinstitucionais e psicossociais dos processos de saúde e doença. Revista HISTEDBR, 33, 207-227

Rother, E. T. (2007). Revisão narrativa vs revisão sistemática. Acta Paulista de Enfermagem, 20, 6-7.

Shaukat, S., \& Iqbal, H. M. (2012). Teacher self-efficacy as a function of student engagement, instructional strategies and classroom management. Pakistan Journal of Social and Clinical Psychology, 9 (3), 82-85.

Silva, A. J., Iaochite, R. T., \& Azzi, R. G. (2010). Crenças de autoeficácia de licenciandos em Educação Física. Motriz, 16, 942-949. *

Skaalvik, E. M., \& Skaalvik, S. (2007). Dimensions of teacher self-efficacy and relations with strain factors, perceived collective teacher efficacy, 
and teacher burnout. Journal of Educational Psychology, 99, 611-625. doi:10.1037/0022-0663.99.3.611

Skaalvik, E. M., \& Skaalvik, S. (2010). Teacher self-efficacy and teacher burnout: A study of relations. Teaching and Teacher Education, 26, 10591069. doi:10.1016/j.tate.2009.11.001*

Soodak, L. C., \& Podell, D. M. (1996). Teacher efficacy: Toward the understanding of a multi-faceted construct. Teaching and Teacher Education, 12, 401-411. doi:10.1016/0742-051X(95)00047-N

Sousa, I. F. (2009). Burnout em professores universitários: Impactos de percepção de justiça e comprometimento afetivo. Teoria e Pesquisa, 25, 499-508

Sousa, M. R. de, \& Ribeiro, A. L. P. (2009). Revisão sistemática e metaanálise de estudos de diagnóstico e prognóstico: Um tutorial. Arquivos Brasileiros de Cardiologia, 92 (3): 241-251. doi:10.1590/S0066782X2009000300013

Topkaya, E. Z., \& Yavuz, A. (2011). Democratic values and teacher selfefficacy perceptions: A case of pre-service english language teachers in Turkey. Australian Journal of Teacher Education, 36 (8), 31-49. *

Tschannen-Moran, M. (1998). Teacher efficacy: Its meaning and measure. Review of Educational Research, 68 (2), 202-248.
Tschannen-Moran, M., \& Hoy, A. W. (2001). Teacher efficacy: Capturing an elusive construct. Teaching and Teacher Education, 17, 783-805. doi:10.1016/S0742-051X(01)00036-1

Tschannen-Moran, M., \& Hoy, A. W. (2002). The influence of resources and support on teachers' efficacy beliefs. New Orleans, LA. Paper presented at the annual meeting of the american education research association.

Tschannen-Moran, M., Hoy, A. W., \& Hoy, W. K. (1998). Teacher efficacy: Its meaning and measure. Review of Educational Research, 68 (2), 202-248. doi:10.3102/00346543068002202

Tschannen-Moran, M., \& Johnson, D. (2011). Exploring literacy teachers' self-efficacy beliefs: Potential sources at play. Teaching and Teacher Education, 27, 751-761. doi:10.1016/j.tate.2010.12.005*

Vieluf, S., Kunter, M., \& van de Vijver, F. J. R. (2013). Teacher self-efficacy in cross-national perspective. Teaching and Teacher Education, 35, 92-103. doi:10.1016/j.tate.2013.05.006 *

(Article received: 11-02-2015; revised: 02-09-2015; accepted: 03-06-2015) 